\title{
Abject Selfhood in Toni Morisson's The Bluest Eye
}

\author{
Setefanus Suprajitno
}

\begin{abstract}
The Bluest Eye (TBE) is Toni Morrison's tribute to Afro-American women who are derailed by psychological racism and black complicity. As "a minority in both class and class" (TBE 18), they are defenseless against the insidiousness of psychological racism, which induces them to devalue their self-worth. In this novel Morrison talks about Pecola Breedlove, who is affected by the dominant culture's beauty's standard which results in leading here to her tragic life. Her belief that she is ugly and that the supreme beauty means White and blond is reinforced by commercialism. Therefore she wants to be as White as possible and have a pair of blue eyes, as the ultimate emblem of inclusion, though the White reject her. Having been induced to reject her own culture and being rejected by that which she longs for membership, she is stranded in no man's land. Her self cannot be healthily articulated, having no community to anchor it. Thus she becomes an abject person.
\end{abstract}

Keywords: abject selfhood, The Bluest Eye, Toni Morrison

In a conversation with Charles Ruas, Toni Morrison says, "I began to write about a girl ... and the pain of yearning and wanting to be somebody else ... part of all females who were peripheral in other people's lives" (Ruas 218). She wrote about that girl and her problems in The Bluest Eye (TBE). In this novel Morrison explores racism and sexism as hindrance to the realization of the self. She emphasizes on the effects of the beauty standard of the dominant culture on the self-image of the Afro-American females.

The Bluest Eye talks about Pecola Breedlove who is the most affected by the dominant culture's beauty standard, which results in leading her to her tragic life. She wants her family and friends to love and accept her. She believes that the reason she is despised and not accepted is because she is black and ugly. This feeling stems more from the inner conviction of ugliness arising from her own self-hatred and from her desperate material conditions than from physical imperfections, as the novel describes:

No one could have convinced them [the Breedloves] that they were not relentlessly and aggressively ugly. Except for the father, Cholly, whose ugliness [the result of despair, dissipation, and violence directed towards petty things and weak people] was behavior, the rest of the family ... wore their ugliness, put it on, so to speak, although it did not belong to them. (TBE 34)

The reason why the Breedloves are so ugly is because they fervently believe that they are ugly.

Pecola is the most affected because "she is the poorest, and consequently the most vulnerable“ (Mbalia 28). Set in the early forties, in which economic hardships were intensified for the blacks and reinforced by nature's harshness, Morrison delineates the impossible quest-for-identity task of the Afro-American females. They, "being a minority in both caste and class" (TBE 18), are defenseless against the insidiousness of psychological racism emptying White self-disgust onto the blacks (Ellison, Shadow 124) whose double consciousness induces them to devalue their self-worth. Furthermore, 
Morrison identifies the crass commercialism of the movie and candy wrappers as enforcing White standard of beauty as supreme with blue eyes as the ultimate emblem of inclusion.

The Dick-and-Jane sensibility and the ideal "beauty" it represents, which is blond and blue-eyed reinforce the belief that they are ugly. The Dick-Jane primer praising the White ideal concept of the American family is used structurally by Morrison as an ironic comment on the distance of the black family from it. Michael Awkward sees Morrison's manipulation of the primer as "her refusal to allow the White voice to arbitrate success or failure of the black experience" (59). She also distorts its type-print to indicate its function as the metaphor of psychological deformity of the black women who imbibe White standards as the Breedloves do, resulting in self-hatred and alienation from their culture and community. They become mutilated self or totally eradicated self in abject insanity.

The Black community is marginalized by being poor and black. Living on the edges of White society, they are constantly bombarded by the perfect, unattainable images of the dominant White culture. Black girls are taught to measure themselves against the Shirley Temple ideal and find themselves lacking (Klotman, "Dick and Jane and the Shirley Temple"). The most cherished Christmas present is a White girl doll: "adults, older girls, shops, magazines, newspaper, window signs - all the world agreed that a blue-eyed, yellow-haired, pink-skinned doll was what every girl child treasured" (TBE 20 ). So the self-image of the Black is destroyed at an early age as a result of the ruling class's, in this case, the White's, promotion of its own standard of beauty. If the physical features of the White are accepted as the standard of beauty, then the Black must be ugly. This is what the Breedloves use to convince themselves that they are ugly.

They had looked about themselves and saw nothing to contradict the statement; saw, in fact, support for it leaning at them from every billboard, every movie, every glance. "Yes," they had said. "You are right." And they took the ugliness in their hands, threw it as a mantle over them, and went about the world with it. (TBE 34).

The most beautiful Black women look almost White. Maureen Peel is envied less for her family's wealth than for her fairness. Just as Pecola Breedlove assimilates the specious values of self-worth from the White world, her mother, Pauline Breedlove receives her education in self-hatred from the silver screen where, she was introduced to the White physical beauty. After she works for some time with the Fishers, a White family, she begins to adopt their values and lifestyle, as they are more meaningful than her own.

More and more she neglected her house, her children, her man - they were like the afterthoughts one has just before sleep, ... the dark edges that made the daily life with the Fishers lighter, more delicate, more lovely. ... Here she found beauty, order, cleanliness, and praise. (101)

She equates "physical [White] beauty with virtue," and collects "self-contempt by the heap" (TBE 97), a receptacle for her self-hatred. It is this self-hatred that causes her to condemn her daughter as ugly (TBE 100). Nowhere is this more clearly seen than the scene where Pecola accidentally drops a hot blueberry pie at the Fisher's kitchen.

In one gallop she [Pauline] was on Pecola, and with the back of her hand knocked her to the floor. Pecola slid in the pie juice, one leg folding under her. Mrs. Breedlove yanked her up by the arm, slapped here again, and in a voice thin with anger, abused Pecola directly and Frieda and me by implication. (TBE 86) 
Pauline shows no concern for Pecola, even though Pecola has been burnt by the hot pie juice. She is outraged because Pecola makes "her" clean floor dirty. That frightens the young daughter of the Fishers and she starts to cry. Seeing that the little pink and yellow girl begins to cry, Pauline comforts her with tenderness, "Hush, baby, hush. Come here. Oh Lord, look at your dress. Don't cry no more. Poly will change it" (86). She says harshly to her own daughter, Pecola, "Pick up that wash and get out of here, so I can get this mess cleaned up" (86). Through her mother's blurred vision of the pink, White, and golden worlds of the Fishers, Pecola learns that she is ugly, unacceptable, and especially unloved.

Pecola is "further removed from community strengths (Russel 44). Michael Awkward writes "Pecola is held up as a figure of supreme ridicule strictly because in her detachment from her cultural heritage, she exists unprotected from the disastrous effects of [Whites] standards that she cannot achieve" (73). Morrison writes that Pecola's lack of self -esteem and "spunk" arises from the fact that almost from the beginning Pecola Breedlove had not been brought up within an environment that stressed black values and self-esteem.

The only way an "uprooted" Black person can survive is to be as White as possible. Of course, such an option is only available to the fair-complexioned or high-yellow Blacks. A similar projection of race self-hatred is seen in Pecola's encounter with Geraldine, a high yellow. Women like Geraldine, trying to live up to the White man's idea of reality, are living without "funk" - these women, beautiful to look at, are taught "how to get rid of funkiness, the dreadful funkiness, the funkiness of nature, the funkiness of the wide range of human emotion" (TBE 68). In Morrison's opinion, if black people want to survive in America, they have to be rooted in their culture and to possess "funk," the "spiritedness," the one which is rooted in culture and Black pride.

Pecola's alienation is more acute, weighed down by black complicity, first imaged in her mother's displacement of self-contempt onto her, as Ralph Ellison describes this complicity at various levels she suffers, "Much of the damage sustained by Negroes begins in the Negroes family and much occurs in the Negro nursery school, the kindergarten and the first few grades (17). He states that their cruelty stems from their own self-dislike.

This self-dislike is rooted in the "deficit" perspective on Afro-American culture. This perspective views that Afro-Americans are "somehow deficient with respect to intelligence, perceptual skills, cognitive styles, family structure, and other factors" (White and Parham 8). In this perspective, environmental factors determine the presumed deficiencies in Afro-Americans. Kardiner and Ovessey, as quoted by White and Parham, write that "it was somehow concluded that the effects of years of racism and discrimination had deprived most Black people of the strengths to develop healthy self-esteem (8). This perspective stresses the notion that "the White culture establishes the normative standards (White and Parham 8). Thus the White beliefs and views become the yardstick of the society, and Afro-American adopts the White reference-group orientation and ascribed identity. In other words, anything different from the White perception is seen as deficient, and this deficit-deficiency perspective is reinforced by the dominant White culture, as seen in the case of the Breedloves.

The self-dislike is symbolized in Pecola's name. As Maureen Peal explains to pecola, it comes from a movie.

"Pecola? Wasn't that name of the girl in Imitation of Life?"

"I don't know. What is that?" 
"The Picture show, you know. Where this mulatto girl hates her mother 'cause she is

That name reflects a figure of self-hatred, or in Alice Walker's word, "colorism," which she defines as "prejudicial or preferential treatment of the same-race people based solely on their color" (290). Colorism is manifested in celebrations over "the birth of a golden child" or the rugings to marry a "high-yellow" in order to lighten up the race" (311). In her opinion, colorism of the Afro-American is "camouflaged by the promise of 'upward mobility,' i.e. proximity to, imitation of and eventual merger with (or, as Chestnut wrote, 'absorption into') the White middle class" (310). This is clearly seen in Pauline and Geraldine.

Through the name Pecola, Pauline learns to devalue herself through fantasies and teaches her daughter a similar sense of unworthiness (Rosenberg 440), which Alice Walker calls as "psychic annihilation." She writes,

"... certainly every Afro-American is descended from a black woman. What then can be the destiny of a people that pampers and cherishes the blood of the White slaveholders who maimed and degraded their female ancestor? What can be the future of a class of a descendants of slaves that implicitly gives slaveholders greater honor than the American women they enslaved?" (295)

Her name calls forth not an authentic Black self, rather a self-displaced into believing that her definition lies in the White world but who discovers their rejection in her experiences with White men whose White eyes suggest a distaste for blackness.

Far worse is the rejection from her own people. In school, the playhouse, and Geraldine's house, she is considered as the eruption of "the dreadful funkiness" (TBE 68), reminding characters like Geraldine of their earthy blackness, which they regard as insulting and humiliating. By showing contempt for Pecola, they displace their humiliation on her. Her intense consumption of White milk in Shirley Temple cup, or just holding the cup with the silhouette of Shirley Temple's (TBE 22), and ingesting candy wrapped in Mary Jane wrapper - the smiling White face with its "blue eyes looking at her out of a world of clean comfort ... . To eat the candy is somehow to eat the eyes. Eat mary janes. Love mary jane, Be Mary Jane (TBE 43) - come to no avail as insults of "Black and ugly e mos" (TBE 61) are still being hurled at her; a grim inversion of the consumption motif occurs in that her Black self has been devoured by these White images of beauty. Thus, she is stranded in no man's land, having been induced to reject her own culture and being rejected by that which she longs for membership; her self cannot be healthily articulated having no community to anchor it.

Pecola is an abject character gripped by "a violent dark revolt of being." Julia Kristeva defines abjection as a state in which the abject is opposed to herself, experiencing "a violent dark revolt of being, directed against a threat that seems to emanate from an exorbitant outside or inside" (10). What characterizes the abject person is that she has not fully integrated her subjectivity, because she derives her being from an all-powerful, overpowering other. A person experiences an abjection "only if an Other has settled in place and stead of what will be [her]. Not at all another with whom [she can] identity and incorporate, but an other who precedes and possesses [her] and through such possession cause [her] to be" (Kristeva 10). Because the abject is defined by the Other, and seeks her being within the Other, she is always gripped with longing for the unattainable, and pursues pseudo-objects instead which offer her a modicum of satisfaction. The pseudo-object in this novel and Pecola pursues is definitely 
blue eyes. Claudia says that "each night, without fail, she [Pecola] prayed for blue eyes. Fervently, for a year she had prayed" (TBE 40).

The abject person is also "an ego, wounded to the point of annulment, barricaded and untouchable, cower[ing] somewhere, nowhere, at no other places than the one that cannot be found" (Kristeva 47). In The Bluest Eye certain sectors of Black population are preceded and possessed by the White race which function as their Other, with whom they identify and long to be like. Yet this identification is hopeless because the White standards of beauty are impossible to achieve, resulting in the black person's subsequent abjection. Because the abject person derives her being within the Other, and longs to resemble the Other as closely as possible, she is always in pursuit of the "pseudo-object" which functions as a kind of life preserver. The pursuit of pseudo-object is vividly seen in Pecola's case, who longs for blue eyes, the epithome of "whiteness," because she believes they will grant her happiness (TBE 40). Because she is determined to change the color of her eyes into blue, Pecola meets a faithhealer, Soaphead Church, who promises them to her because he is "wholly convinced that if Black people were more like White people they would be better off" (Stepto 223). Soaphead Church says,

I, I have caused a miracle. I gave here the eyes. I gave her the blue, blue, two blue eyes. Cobalt blue. A streak of it right out of your own blue heaven. No one else will see her blue eyes. But she will. And she will live happily ever after. I, I have found it meet and right to do so." (143).

Pecola pays them with her own sanity. After being raped by his father, she becomes mad and wanders through the town dump, babbling about her blue eyes.

What? What we will talk about?

Why, your eyes.

Oh, yes, My eyes. My blue eyes. Let me look again.

See how pretty they are.

Yes, They get prettier each time I look at them. ...

Prettier than the sky?

Oh, yes. Much prettier than the sky.

Prettier than Alice-and-Jerry Storybook eves?

Oh, yes. Much prettier than Alice-and-Jerry Storybook eyes. (156)

Pecola's abjection hinders her attempts to integrate her subjecthood. Born into a loveless and violent family, Pecola is rejected at birth by her mother because of her ugliness, scorned and turned into a joke by her schoolmates and victimized by her community. The Breedloves, in spite of the name, are unable to show Pecola the love that would mitigate her rejection by society. The Breedlove family, with its ironic pun on its name, is both loveless and deracinated psychologically and economically. Pecola's ego is constantly being denied the opportunity to develop. She is Morrison's grim representative of those Black girls whose potential for authentic womanhood and identity is ruthlessly curtailed by the effects of imposing White ascribed identity.

In The Bluest Eye, Morrison also questions the imposition of White ascribed identity, which results in the "deficit" perspective in Black culture. Claudia, the narrator in The Bluest Eye, is the voice questioning the myth of White beauty as supreme in her disremembering of the White doll to search for its authenticity and power; she finds only a "mere metal roundness" (TBE 21). Even though her family also lives in the marginal level of societal acceptance, just like the Breedlove family, Claudia is able to learn and mature because her family has the inner strength to withstand the poverty and discrimination of a racist society and to provide and environment where the children can 
grow. She also discovers in the blues her mother sings the values of toughness and resilience which have helped her race transcend difficulties throughout its history in a racist America (Baker 11). She is also the voice assuming responsibility for her community's shabby treatment of Pecola in that "all of us - all who knew her - felt so wholesome after we cleaned ourselves on her" (TBE 159). But her awareness of her fraudulent love for Whites and her confession that "change [is] adjustment without improvement" (TBE 22) indicate her failure to achieve an authentic selfhood. Though she gives voice to authenticating Black girlhood and demonstrates "some control over her life" (Frye 108), hers is nevertheless a failed voice for which complete selfhood has yet to be articulated.

Thus, The Bluest Eye is Morrison's tribute to the countless number of Black females whose attempts to search for their authenticity and identity are derailed by the deficitdeficienty perspective in their own culture, voicing their cries as the bluest "I".

\section{References}

Awkward, M (1989). Inspiriting influences: Tradition, revision and Afro-American women's novels. New York: Columbia UP.

Baker, H. A., Jr. (1984). Blues, ideology and Afro-American literature: A vernacular theory. Chicago: Chicago UP.

Ellison, R. (1967). Shadow and act. London: Secker and Warburg.

Ellison, R. (1986). What These Children Are Like? In R. Ellison (ed.), Going to the Territory. New York: Random House. 64-75.

Fyre, J. S. (1986). Living stories, telling lives: Women and the novel in contemporary experience. Ann Arbor: University of Michigan Press.

Koltman, P. R. (1979). Dick and Jane and the Shirley Temple Sensibility in The Bluest eye. In Black American Literature Forum. Vol. 13 No. 4: 123-25.

Kristeva, J. (1982). Powers of horror: An essay on abjection. (trans. Leon S. Roudiez). New York: Columbia UP.

Mbalia, D. D. (1991). Toni Morrion's developning class consciousness. Selinsgrove: Susquehanna UP.

Morrison, T. (1972). The Bluest eye (1970). New York: Washington Square Press.

Rosenberg, R. (1987). Seeds in hard ground: Black girlhood in The Bluest eye. In Black American Literary Forum. 4: 435-445.

Ruas, C. (1986). Toni Morrison. In C. Ruas (ed.), Conversation with American Writers. New York: McGraw Hill. 215-243.

Russel, S. (1988). 'It's OK to say OK' [An Interview Essay]. In Nelly Y. McKay (ed.), Critical essays on Toni Morrison. Boston: G. K. Hull and Co. 57-68.

Stepto, R. B. (1979). Intimate things in place: A Conversation with Tony Morrison. In Michael S. Harper and Robert B. Stepto (ed.), Chants of Saints: A Gathering of 
Afro-American literature, art, and scholarship. Urbana: University of Illinois Press. 213-229.

Walker, A. (1983). In search of our mothers' gardens: Womanist prose. New York: Harcourt.

White, J. L., and Parham, T. A. (1990). The psychology of Blacks: An AfricanAmerican perspective. $2^{\text {nd }}$ ed. Englewood Cliffs, NJ: Prentice Hall. 